\title{
A New Added-Value Application for Steel Wire Drawing Mill Scale Waste in Stoneware Ceramic Products
}

\author{
Inês Silveirinha Vilarinho ${ }^{1, *(\mathbb{D})}$, Ana Luisa Lopes ${ }^{1}$, Jorge Carneiro ${ }^{2} \mathbb{D}$, Carlos Pinto ${ }^{2}$, João António Labrincha ${ }^{1}(\mathbb{D}$ \\ and Maria Paula Seabra ${ }^{1, *(D)}$ \\ 1 Department of Materials and Ceramic Engineering, CICECO—Aveiro Institute of Materials, University of \\ Aveiro, 3810-193 Aveiro, Portugal; analuisalopes@ua.pt (A.L.L.); jal@ua.pt (J.A.L.) \\ 2 Grestel—Produtos Cerâmicos S.A, Zona Industrial de Vagos-Lote 78, 3840-385 Vagos, Portugal; \\ jorgecarneiro@grestel.pt (J.C.); carlospinto@grestel.pt (C.P.) \\ * Correspondence: inessvilarinho@ua.pt (I.S.V.); pseabra@ua.pt (M.P.S.)
}

check for

updates

Citation: Vilarinho, I.S.; Lopes, A.L.; Carneiro, J.; Pinto, C.; Labrincha, J.A.; Seabra, M.P. A New Added-Value Application for Steel Wire Drawing Mill Scale Waste in Stoneware Ceramic Products. Metals 2021, 11, 661. https://doi.org/10.3390/ met11040661

Academic Editor: Leszek Adam Dobrzanski

Received: 17 March 2021

Accepted: 15 April 2021

Published: 18 April 2021

Publisher's Note: MDPI stays neutral with regard to jurisdictional claims in published maps and institutional affiliations.

Copyright: (c) 2021 by the authors. Licensee MDPI, Basel, Switzerland. This article is an open access article distributed under the terms and conditions of the Creative Commons Attribution (CC BY) license (https:/ / creativecommons.org/licenses/by/ $4.0 /)$.

\begin{abstract}
Mill scale (MS) is a iron-rich waste generated in the wire drawing process with high iron content and is still mainly disposed in landfills. The scientific community has been studied its use in other applications such as pigments, concretes, among others. This work aims to study a new added-value application for MS-the development of coloured ceramic pastes. For this purpose, the influence of the added amount $(0,1,3,5$ and $10 \mathrm{wt} . \%)$, the pre-treatment (milling + sieving at $212 \mu \mathrm{m}$ ), the maximum firing temperature (from 1043 to $1165^{\circ} \mathrm{C}$ ) and the type of furnace (laboratory/industrial) were analysed on the sample's characteristics. A dark grey stoneware product was obtained through the incorporation of $10 \mathrm{wt} . \%$ of MS and leaching tests conducted at pilot scale with cups confirmed its immobilization in the ceramic matrix. Furthermore, it was proved that the firing temperature can be reduced by about $100{ }^{\circ} \mathrm{C}$ without affecting the specimen's characteristics. This reduction leads to a considerable decrease in the energy consumption upon firing, inducing economic and environmental advantages. Therefore, this work provides a new added-value application for MS and contributes to the reduction of virgin raw materials consumption and development of more sustainable stoneware products.
\end{abstract}

Keywords: mill scale; waste valorization; stoneware ceramics; circular economy; industrial symbiosis

\section{Introduction}

Population growth and the consequent economic development impose an increase in goods demand and raw materials and energy consumption, which can generate scarcity of natural resources and also the increase of the amount of generated wastes [1]. Nowadays, solid waste management is one of the major worldwide concerns. Improper solid waste disposal can lead to substantial negative environmental impacts such as air, soil and water pollution, greenhouse gas emissions and health and safety problems i.e., diseases spread by insects and rodents attracted by garbage heaps and other diseases associated with pollution [2]. In 2018, the total waste generated by the European Union (27 Member States) reached 2.3 billion tonnes, whose final destination included: (i) landfilled, incinerated without energy recovery or disposal otherwise (45.8\%); (ii) recycling (38.1\%); (iii) backfilling (10.1\%); and (iv) incineration with energy recovery $(6.0 \%)$ [3]. The United Nations defined the 2030 Agenda, involving 17 Sustainable Development Goals. Goal 12 attempts to ensure sustainable consumption and production patterns, aiming to achieve sustainable management and the efficient use of natural resources. Furthermore, it includes the substantial reduction of waste through prevention, reduction, recycling and reuse [4].

Metals are one of the most important types of materials mainly due to their properties in terms of fracture toughness, thermal and electrical conductivity and performance at high temperatures. Therefore, this family of materials is, nowadays, used in a wide range of 
applications such as in the areas of machinery, energy, transportation, construction, information technology and electrical appliances [5]. Steel wire production has a global market evaluated at $€ 78$ billion in 2018 with an expected compound annual growth rate, CAGR, of $2.7 \%$ between 2018 and 2026 [6]. A wire drawing machine is normally used to reduce the cross-section of the wire by pulling it through a series or single-drawing dies. This process generates a solid waste, commonly known as mill scale (MS), that is rich in iron oxides, namely: $\mathrm{Fe}_{2} \mathrm{O}_{4}, \mathrm{Fe}_{2} \mathrm{O}_{3}$ and $\mathrm{FeO}$ [7]. The mill scale represents about $2 \%$ of the total produced wire and, in 2019, $\approx 37$ million tonnes of MS were generated worldwide [8,9]. Numerous efforts for recycling MS have been implemented, either internally or by distinct industrial sectors. However, a substantial quantity of mill scale is still disposed of in landfills since no viable technology was developed to massively recycle the waste [9-11]. On this wise, the scientific community together with the industrial sector has been trying to develop new high add-value applications. To recover the iron from the mill scale, the reduction of the iron oxides is required. This reduction can be conducted in a blast furnace in the presence of an external reducing agent or a carbon powder waste [12]:

$$
\begin{gathered}
x \mathrm{C}(s)+x \mathrm{CO}_{2}(g) \rightarrow 2 x \mathrm{CO}(g) \\
\mathrm{Fe}_{x} \mathrm{O}_{y}(s)+y \mathrm{CO}(g) \rightarrow x \mathrm{Fe}(s)+y \mathrm{CO}_{2}(g) .
\end{gathered}
$$

Nevertheless, due to the high energy consumption and greenhouse gas emissions, other applications have been studied, including: pigments [13,14]; briquettes, to be reintroduced in the liquid steel transformation as a ferrous source [15]; concrete production, to increase the compressive strength and decrease the electrical resistivity [16-18]; bipolar plates, a multi-functional component of proton exchange membrane (PEM) fuel cell [19]; production of FeCo alloy [20] among others.

Iron oxide-based pigments are widely used, for example, in paints, coatings, enamels, and plastics [21]. Therefore, the preparation of iron oxide pigments from mill scale has been studied, more specifically, high-quality iron oxide pigments, namely magnetite, goethite, hematite and maghemite, from mill scale were studied [11,22]. The authors concluded that it was possible to obtain pigments with acceptable purity and good morphological properties through simple and cost-effective methods. The development of anti-corrosive paints using mill scale was also studied [23]. Different incorporation levels (1 to $15 \mathrm{wt} . \%)$ in two commercial paints were tested and the authors concluded that, for each paint, there is an optimum concentration of MS regarding its anti-corrosion properties. Additionally, the preparation of ceramic glazes from steel waste was investigated [21]. The authors observed that the mill scale pre-treatment (mechanical and thermal) and added amount (1 and $10 \mathrm{wt} . \%$ ) influenced the glaze brownish hue.

In the ceramic industry, the interest on coloured pastes has been rising mainly due to the various aesthetic effects resulting from the surface relief of the pieces. Moreover, coloured pastes simplify the ceramic production process since the same glaze can be used, reducing the wasted amount and the time spent to change it. In addition, a problem that ceramic industries are facing nowadays is the need to camouflage possible contaminants resulting from the re-utilization of industrial waste/by-products. Consequently, the present work aims to investigate a new value-added application for the mill scale as a colouring agent of stoneware pastes. Different MS proportions, type of furnace and firing temperature were tested. Pilot-scale produced cups were subjected to leaching tests in order to check the iron oxide immobilization and provide the proof of the concept of using mill scale in this application.

\section{Materials and Methods}

\subsection{Materials}

A typical stoneware ceramic paste provided by Grestel-Produtos Cerâmicos S.A. was used for the incorporation of mill scale (MS) generated by Fapricela-Indústria de Trefilagem 
S.A. Dolapix PC67 was the commercial deflocculant added to adjust the viscosity of the slurry. Finally, for the leaching experiments, glacial acetic acid, from Fisher Chemical, was used.

\subsection{Samples Preparation}

Mill scale was subjected to a pre-treatment in order to evaluate the effect of its granulometry on the characteristics of the samples. The MS was grounded on a Retsch RS 100 ring mill at $1400 \mathrm{rpm}$ for about one minute, followed by sieving at $212 \mu \mathrm{m}$. Several amounts ( 1 to $10 \mathrm{wt} . \%$ ) of the waste were incorporated into the stoneware paste. Moreover, the material in the as received condition was incorporated in the highest concentration (10 wt.\%), as shown in Table 1. The numbers express the added amount of MS and $\mathrm{r}$ means as received mill scale.

Table 1. Tested compositions.

\begin{tabular}{ccccccc}
\hline Samples & MS0 & MS1 & MS3 & MS5 & MS10 & MS10r \\
\hline & \multicolumn{7}{c}{ (wt.\%) } \\
\hline Stoneware Paste & 100 & 99 & 97 & 95 & 90 & 90 \\
MS (pre-treated) & - & 1 & 3 & 5 & 10 & - \\
MS (as received) & - & - & - & - & - & 10 \\
\hline
\end{tabular}

To produce the samples, the following steps were used: (i) slurry preparation; (ii) conformation by slip casting; (iii) drying and firing. The suspensions were homogenized in a turbo diluter and the determination of the amount of suspension to be used in the different formulations was calculated using the Brongniart formula [24]:

$$
\mathrm{W}=(P-1000) \frac{s}{s-1},
$$

where $\mathrm{W}$ is the weight $(\mathrm{g})$ of solids in $1000 \mathrm{~mL}$ of slurry, $P$ is the target density of the slurry $\left(\mathrm{g} / \mathrm{cm}^{3}\right)$ and $\mathrm{s}$ is the specific gravity of the dried ceramic material for which the value of $2.6 \mathrm{~g} / \mathrm{cm}^{3}$ was considered. Subsequently, the respective MS amount was added to each of the formulations (Table 1) and the suspension was homogenized, once again, using the turbo diluter. Finally, the slip density was adjusted to $1725 \mathrm{~g} / \mathrm{cm}^{3}$ (by adding water), and the viscosity to $30 \mathrm{~s}$ in a $4 \mathrm{~mm}$ Ford cup (by adding Dolapix PC67) which are the values used industrially for the slip casting process [25].

In this work, two types of samples were prepared: specimens $\left(10.8 \times 1.8 \times 0.9 \mathrm{~cm}^{3}\right.$, see Figure 1) and cups (height $=7.3 \mathrm{~cm}$ and diameter $=7.2 \mathrm{~cm}$ ). For this purpose, the slips were sieved (at $425 \mu \mathrm{m}$ ) and cast into gypsum moulds. In the case of cups, to reach the desirable wall thickness, the cast lasted $30 \mathrm{~min}$ and then the excess slip was poured out of the mould. In both cases, the samples remained in the mould overnight, at room temperature, being removed afterwards. The drying procedure was: 1 day at room temperature and then $12 \mathrm{~h}$ at progressively higher temperatures $\left(40,80\right.$ and $120{ }^{\circ} \mathrm{C}$ ). The specimens were fired in two furnaces: laboratory and industrial. The laboratory furnace is a muffle and has air ventilation while the industrial one operates continuously and can achieve faster cooling rates. Nevertheless, the firing cycle used was similar in both cases and had the following steps: (i) heating rate of $3{ }^{\circ} \mathrm{C} / \mathrm{min}$ until $575{ }^{\circ} \mathrm{C}$ and $30 \mathrm{~min}$ of dwell time; (ii) heating rate of $5^{\circ} \mathrm{C} / \mathrm{min}$ until $770{ }^{\circ} \mathrm{C}$ and $60 \mathrm{~min}$ of dwell time; (iii) heating rate of $5{ }^{\circ} \mathrm{C} / \mathrm{min}$ until the desired maximum temperature and $30 \mathrm{~min}$ of dwell time; and (iv) cooling until ambient temperature. The cups were only fired in the industrial furnace and, before firing, were glazed, at Grestel, with an opaque white glass. The achieved maximum temperatures were measured with Buller rings (from Mantec refractories, reference TR27/84) being $1160^{\circ} \mathrm{C}$ and $1165^{\circ} \mathrm{C}$, respectively.

Additionally, to analyze the influence of the firing temperature on the final properties of specimens containing the highest percentage of residue lower firing temperatures were also posted (until $1043^{\circ} \mathrm{C}$; laboratory furnace). 


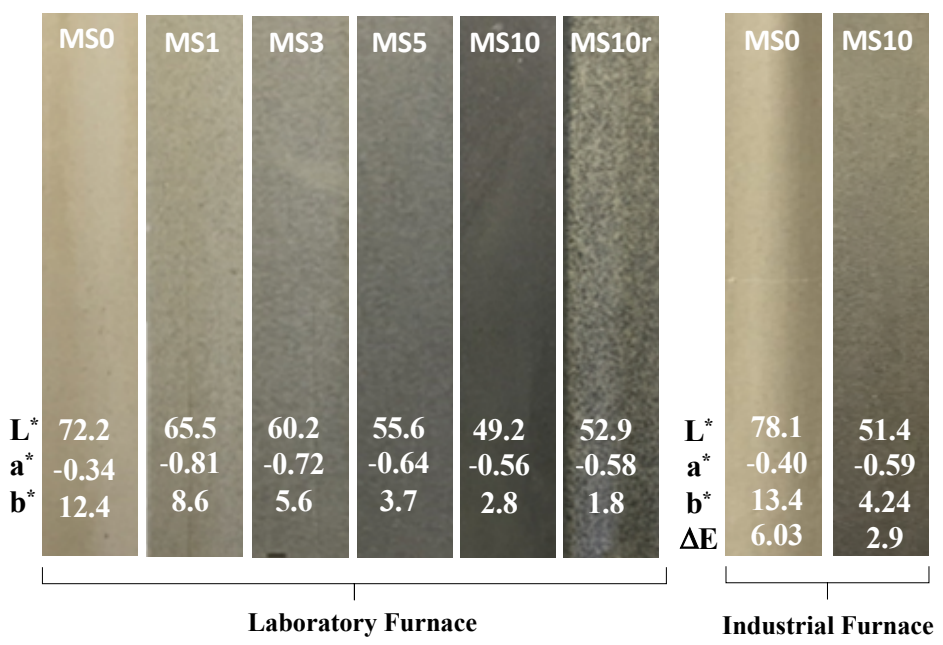

Figure 1. Fired specimens at laboratory and industrial furnaces with the respective colour CIELab coordinates.

\subsection{Characterization Techniques}

2.3.1. Physicochemical Characteristics of Mill Scale

The chemical composition of the MS was obtained by X-ray fluorescence (XRF) in a Philips $X^{\prime}$ Pert PRO MPD spectrometer and the loss on ignition (LOI) at $1000{ }^{\circ} \mathrm{C}$ was also determined. The particle size distribution was obtained by laser diffraction in a Coulter LS analyzer (LS 230, Fraunhofer optical model). Furthermore, the waste as received and after being pre-treated (ground + sieved at $212 \mu \mathrm{m}$ ), was carbon-coated and observed by Scanning Electron Microscopy (SEM, Hitachi S-4100, 25 kV acceleration voltage, Tokyo, Japan). X-ray diffraction (XRD) analyses of the mill scale, at ambient temperature and calcined, were performed using a PANalytical XPert PRO diffractometer (Ni-filtered CuKa radiation, PIXcel 1D detector, and the exposition corresponded to about $2 \mathrm{~s}$ per step of $0.02^{\circ} 2 \theta$ at room temperature).

\subsubsection{Specimens Characterization}

The characterization of the samples was carried out using five replicates in each test. The linear firing shrinkage was evaluated by measuring the length of the specimen before and after being fired. The fired samples were characterized in terms of (i) weight loss (\%) relative to the weight of the dried specimen; (ii) apparent density $\left(\mathrm{g} / \mathrm{cm}^{3}\right)$ determined from the sample weight and size; (iii) water absorption (\%) determined by the difference of weight between the dry specimen and the specimen immersed for $2 \mathrm{~h}$ in boiling water-[26]); (iv) threepoint flexural resistance (MPa) using a universal testing machine (load cell of $20 \mathrm{MPa}$ )Shimadzu Autograph AG-25TA; (v) microstructure of fracture surfaces (Scanning Electron Microscopy/Energy Dispersion Spectroscopy_SEM/EDS, Hitachi S-4100, 25kV acceleration voltage, Tokyo, Japan); and (vi) $\mathrm{L}^{*} \mathrm{a}^{*} \mathrm{~b}^{*}$ colour coordinates using a Konica Minolta Chroma Meter CR-400. The CIEL*a* $b^{*}$ data are expressed as brightness $L^{*}$, changing from 0 (black) to 100 (white), $a^{*}$ (+ red, - green), and $b^{*}$ (+ yellow, - blue) [27]. The difference of the L*a* $b^{*}$ coordinates $(\Delta \mathrm{E})$, between the specimens with the same composition but fired in different furnaces (industrial (ind) and laboratory (lab)), was evaluated as follows:

$$
\Delta \mathrm{E}=\left[\left(\mathrm{L}_{\mathrm{ind}}-\mathrm{L}_{\mathrm{lab}}\right)^{2}+\left(\mathrm{a}_{\mathrm{ind}}-\mathrm{a}_{\mathrm{lab}}\right)^{2}+\left(\mathrm{b}_{\mathrm{ind}}-\mathrm{b}_{\mathrm{lab}}\right)^{2}\right]^{0.5}
$$

where $0<\Delta \mathrm{E}<1$ means that colour differences cannot be perceived by the standard observer; $1<\Delta \mathrm{E}<2$ only perceived by an experienced observer; $2<\Delta \mathrm{E}<3.5$ an inexperienced observer can detect differences; $3.5<\Delta \mathrm{E}<5$ everyone can see the differences [28]. 


\subsubsection{Leaching Experiments}

To perform the leaching tests according to the EU Ceramic Directive 84/500/EEC [29] a solution with $4 \%$ acetic acid $\left(\mathrm{CH}_{3} \mathrm{COOH}\right)$ was prepared. The glazed cups were washed with detergent, tap water and finally distilled water. Once dried, they were filled with the $4 \%$ acetic acid solution and covered with aluminum foil. After $24 \mathrm{~h}$, the solutions were stirred and the amount of lead $(\mathrm{Pb})$, cadmium $(\mathrm{Cd})$ and iron $(\mathrm{Fe})$ were analyzed in an ICP-MS 7700 Thermo X Series. According to the EU Ceramic Directive 84/500/EEC, stock solutions were prepared: (i) $1000 \mathrm{mg} / \mathrm{L}$ of lead in 4 vol.\% acetic acid solution and (ii) at least $500 \mathrm{mg} / \mathrm{L}$ of cadmium in $4 \mathrm{vol} \%$ acetic acid solution. In addition, it was guaranteed that the detection limit for lead and cadmium was equal or lower than the required by the EU Ceramic Directive 84/500/EEC: $0.1 \mathrm{mg} / \mathrm{L}$ for lead and $0.01 \mathrm{mg} / \mathrm{L}$ for cadmium. The detection limit for lead used in this work was $0.001 \mathrm{mg} / \mathrm{L}$. The maximum permitted values of lead and cadmium are 200 and $20 \mu \mathrm{g} / \mathrm{L}$, respectively, according to the EU Ceramic Directive 84/500/EEC. However, for iron, the EU legislation has not defined any limits until the present date but according to the Council Directive 98/83/EC [30], the maximum concentration of total iron in drinking water for human consumption is $200 \mu \mathrm{g} / \mathrm{L}$.

\section{Results and Discussion}

\subsection{Mill Scale Characterization}

The chemical composition and loss on ignition (LOI) of the mill scale were determined, see Table 2 . As expected, the main component is iron $(\approx 97.5 \mathrm{wt} . \%)$ and the LOI value is almost null (0.01 wt.\%).

Table 2. Average chemical composition of MS.

\begin{tabular}{cccccccccc}
\hline Component & $\mathrm{Fe}_{2} \mathrm{O}_{3}$ & $\mathrm{Cu}$ & $\mathrm{SiO}_{2}$ & $\mathrm{MnO}$ & $\mathrm{Al}_{2} \mathbf{O}_{3}$ & $\mathrm{CaO}$ & $\mathrm{MgO}$ & $\mathrm{Cr}$ & LOI \\
\hline wt. $\%$ & 97.53 & 1.12 & 0.46 & 0.4 & 0.1 & 0.07 & 0.07 & 0.07 & 0.01 \\
\hline
\end{tabular}

SEM micrographs of MS, as received and ground, (Figure 2), confirmed these results and showed that particles have an irregular shape. The particle size distribution of the MS, as received and ground, is shown in Figure 3. The median diameter, D50, of the as-received material is about $250 \mu \mathrm{m}$ and the D75 is $425 \mu \mathrm{m}$. Due to the possible particle's agglomeration during these analyses, the as-received MS was sieved through a $425 \mu \mathrm{m}$ sieve being the non passant fraction only $0.2 \mathrm{wt}$.\% which means that almost all particles have a diameter below $425 \mu \mathrm{m}$. Moreover, as expected, the milling of MS promoted a considerable decrease of the particle size, D50 $\approx 50 \mu \mathrm{m}$ and about $98 \%$ of the particles $<200 \mu \mathrm{m}$. Therefore, for the incorporation of MS in the stoneware paste, a sieve mesh of $212 \mu \mathrm{m}$ was used.

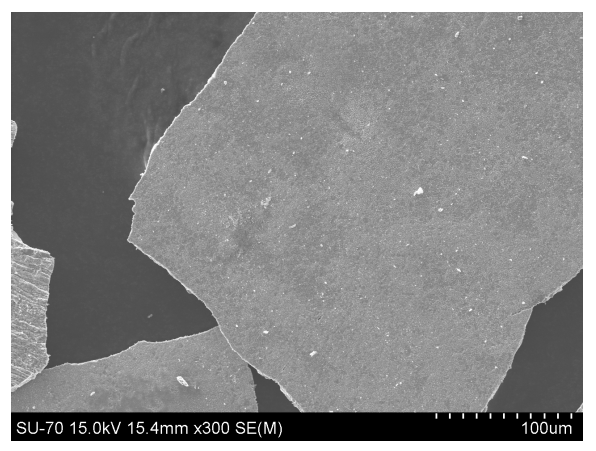

(a)

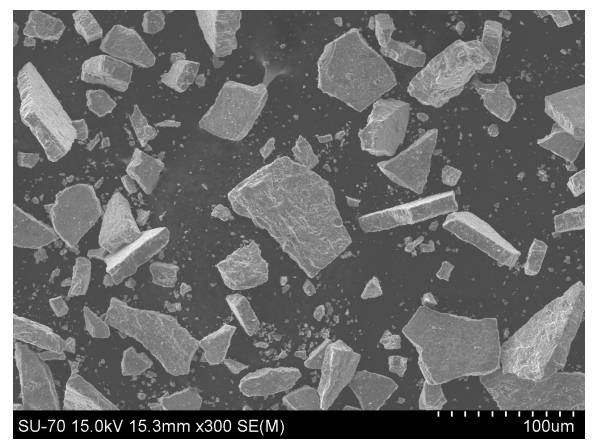

(b)

Figure 2. SEM mill scale micrographs: (a) as received, (b) grinded. 


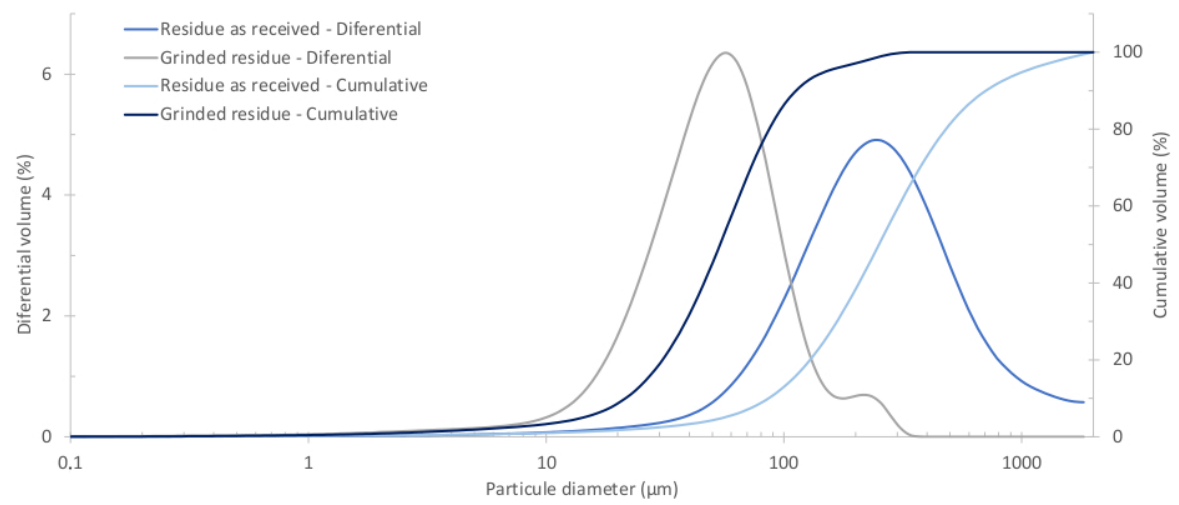

Figure 3. Particle size distribution of MS.

The crystalline phases of MS were also analysed (Figure 4) and according to the XRD result the as received MS has two crystalline phases: wuestite $(\mathrm{FeO})$ and magnetite $\left(\mathrm{Fe}_{3} \mathrm{O}_{4}\right)$. After calcination at $1160{ }^{\circ} \mathrm{C}$ the material exhibits a higher crystallinity and only one crystalline phase was detected: $\alpha-\mathrm{Fe}_{3} \mathrm{O}_{4}$ (hematite)-Figure $4 \mathrm{~b}$. In fact, magnetite and wuestite undergo thermal transformations in the presence of air and, in both cases, the final product is hematite [31]:

$$
\begin{gathered}
\underbrace{\mathrm{Fe}_{3} \mathrm{O}_{4}}_{\text {Magnetite }} \stackrel{\mathrm{O}_{2}, \mathrm{~T}}{\longrightarrow} \underbrace{\alpha \mathrm{Fe}_{2} \mathrm{O}_{3}}_{\text {Hematite }} \\
\underbrace{\alpha \mathrm{FeO}}_{\text {Wuestite }} \stackrel{\mathrm{O}_{2}, \mathrm{~T}}{\longrightarrow} \underbrace{\mathrm{FeO} \cdot \mathrm{Fe}_{2} \mathrm{O}_{3}}_{\text {Magnetite }} \stackrel{\mathrm{O}_{2}, \mathrm{~T}}{\longrightarrow} \underbrace{\alpha \mathrm{Fe}_{2} \mathrm{O}_{3}}_{\text {Hematite }}
\end{gathered}
$$

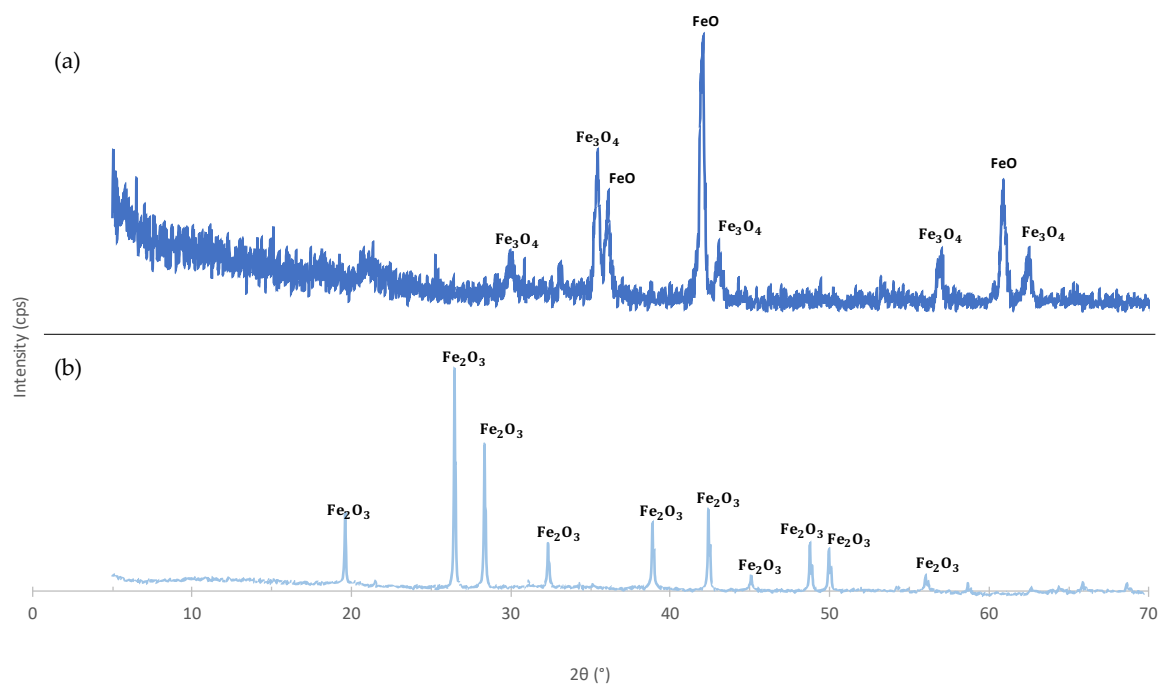

Figure 4. X-ray diffraction (XRD) patterns of mill scale: (a) as received; (b) calcined at $1160{ }^{\circ} \mathrm{C}$.

\subsection{Specimens Characterization}

The crystalline phases of the stoneware paste, with and without the incorporation of MS, fired at $1160{ }^{\circ} \mathrm{C}$ were analyzed and the XRD patterns are presented in Figure 5 . The main difference between the two patterns of the stoneware is that the paste with mill scale exhibits one more phase: hematite. This shows that the phase transformations of the MS are maintained when incorporated in the stoneware paste. 


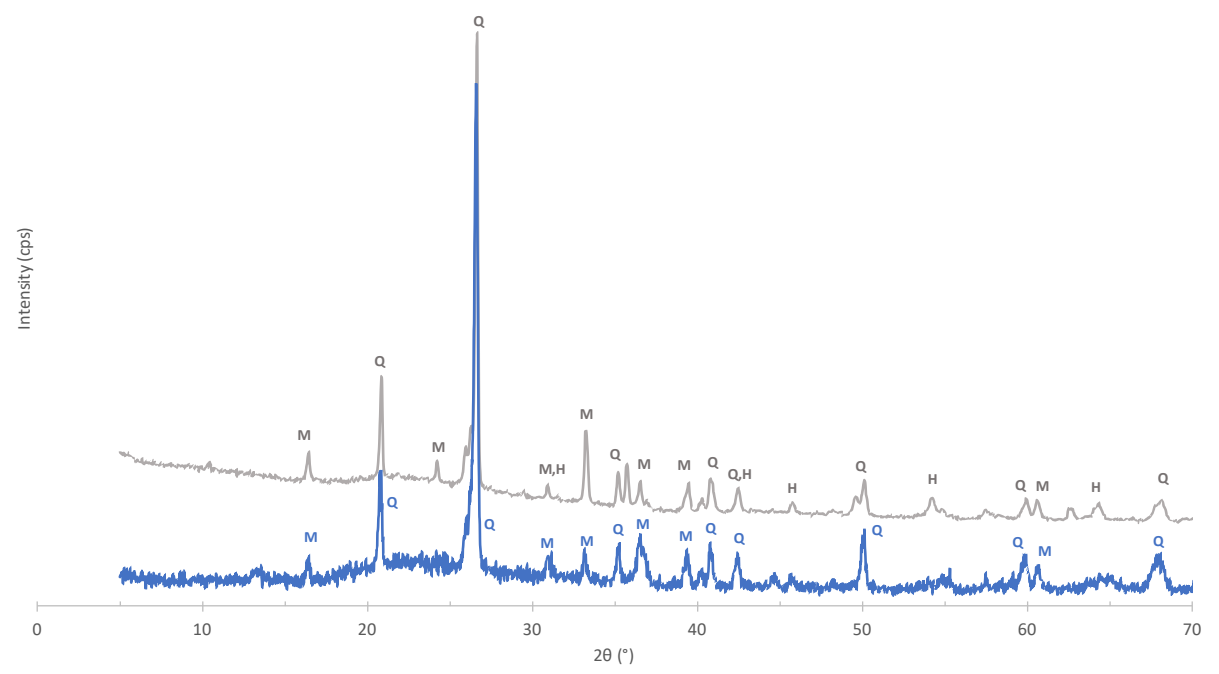

Figure 5. XRD of fired specimens without and with MS, bottom and top, respectively: M-mullite; Q-quartz; H-hematite.

Values of shrinkage upon firig, in laboratory and industrial furnaces, are presented in Figure 6. Herein, it is possible to observe that the samples fired in the industrial furnace always exhibit lower values which might indicate that a lower densification degree was attained. This is explained by the faster cooling obtained with the industrial kiln. Nevertheless, the linear firing shrinkage (LFS) values for most of the tested compositions are within the industrial limits, $7 \%$ (Figure 6). The weight loss, geometric density and water absorption of the prepared samples are presented in Table 3. The incorporation of MS decreases the weight loss due to the almost null LOI value of the waste. Accordingly, MS10 and MS10r specimens present the lowest values $(\approx 4.7 \mathrm{wt} . \%)$ since they contain a lower amount of ceramic compounds. All specimens exhibit values below the industrial limit (7 wt.\%). Regarding the density, it is observed that it rises with the increase of the MS amount whereas the water absorption decreases. The water absorption values are below the company's limits (2-3\%) and below the reference, MS0, $0.2 \%$. Furthermore, it is also possible to notice that the density and the water absorption of the MS3 and MS10 samples are very similar, which confirms that $3 \mathrm{wt} . \%$ of MS gives rise to a sufficient amount of liquid phase to promote the densification of the sample and that the addition of a higher percentage of MS does not contribute to higher densification.

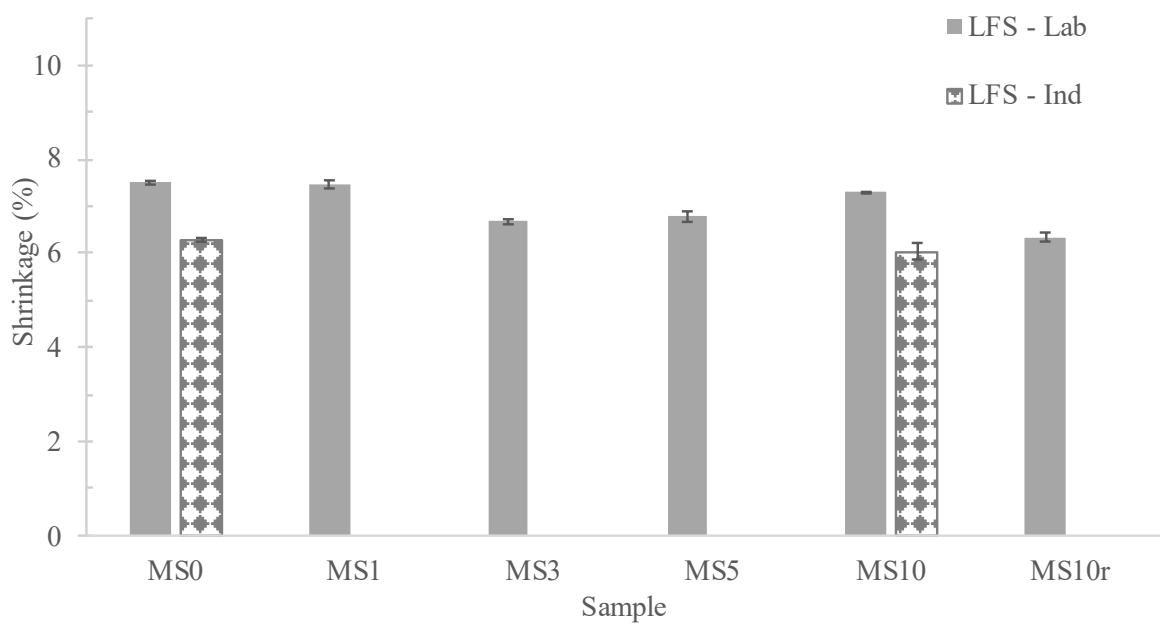

Figure 6. Effect of the MS amount, performed pre-treatment and furnace on the specimens firing and total shrinkage, LFS and LTS respectively. 
The flexural strength of the prepared specimens was evaluated and the results are presented in Figure 7. It can be observed that the incorporation of MS promotes an increase of the specimen's mechanical strength (from $35 \mathrm{MPa}$ to $45 \mathrm{MPa}$, MS0 and MS3, respectively). However, the values stabilize for amounts greater than $3 \mathrm{wt} . \%$, reaching $44.9 \mathrm{MPa}$ and $45.5 \mathrm{MPa}$ for MS5 and MS10, respectively. This fact can be related to the quantity of the liquid phase formed during sintering. The amount resulting from the incorporation of 3-5 wt.\% of MS seems to be sufficient to fill the sample's porosity and promote its almost total densification. The addition of larger amounts of MS no longer affects the densification of the sample but does not deteriorate the properties. Consequently, it can be concluded that it is possible to add up to $10 \mathrm{wt} . \%$ of MS. Comparing the flexural strength of the samples sintered in the laboratory and industrial furnaces, MS0 and MS10, it is observed that higher values were obtained at the laboratory. This is coherent with the higher maturation achieved in lab conditions, c.f. Table 3. Moreover, the flexural strength values are within the limits imposed by the company: 30-50 MPa.

Table 3. Influence of the MS amount, pre-treatment and firing conditions on weight loss (WL), water absorption (WA) and geometric density (D) of the samples.

\begin{tabular}{ccccccccc}
\hline Sample & \multicolumn{2}{c}{ MS0 } & MS1 & MS3 & MS5 & \multicolumn{2}{c}{ MS10 } & \multicolumn{2}{c}{ MS10r } \\
\hline Furnace & Lab & Ind & & Lab & & Lab & Ind & Lab \\
\hline WL $(\%)$ & $6.01 \pm 0.06$ & $5.9 \pm 0.1$ & $6.09 \pm 0.02$ & $5.77 \pm 0.05$ & $5.56 \pm 0.08$ & $4.80 \pm 0.09$ & $4.60 \pm 0.03$ & $4.7 \pm 0.1$ \\
WA (\%) & $0.2 \pm 0.02$ & $0.47 \pm 0.02$ & $0.18 \pm 0.02$ & $0.16 \pm 0.02$ & $0.06 \pm 0.02$ & $0.07 \pm 0.02$ & $0.04 \pm 0.02$ & $0.07 \pm 0.02$ \\
$\mathrm{D}\left(\mathrm{g} / \mathrm{cm}^{3}\right)$ & $2.24 \pm 0.01$ & $2.14 \pm 0.01$ & $2.26 \pm 0.01$ & $2.32 \pm 0.01$ & $2.38 \pm 0.01$ & $2.39 \pm 0.01$ & $2.26 \pm 0.01$ & $2.27 \pm 0.01$ \\
\hline
\end{tabular}

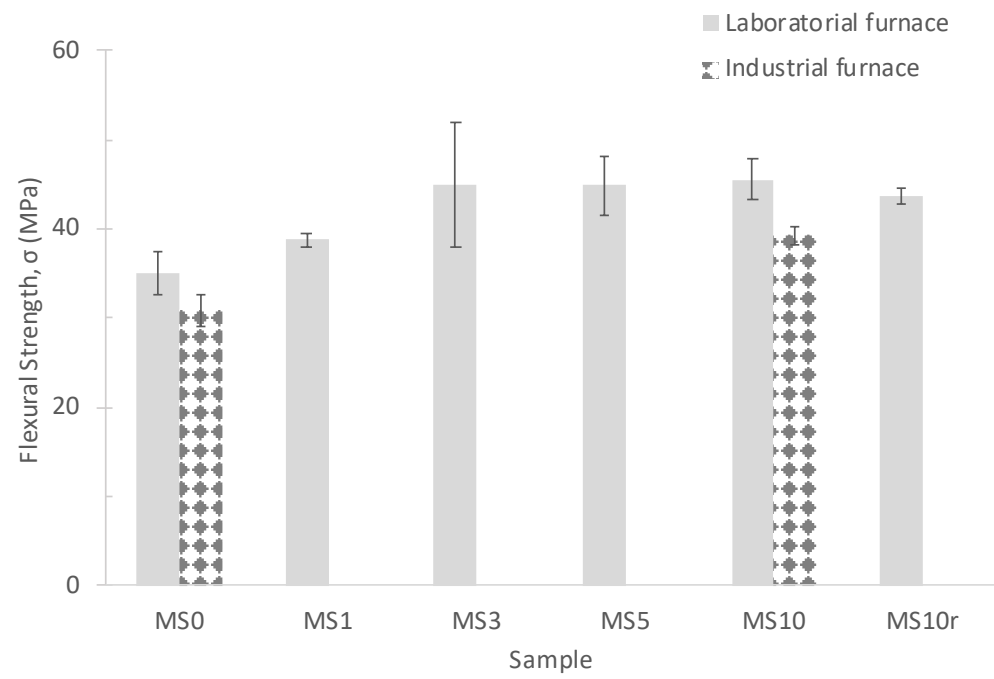

Figure 7. Effect of the MS amount, performed pre-treatment and furnace on the flexural strength of the specimens.

The look of the samples, in particular the colour, changes with MS amount (see Figure 1). For instance, the increase of MS amount promotes a notorious rise of the developed colour intensity being the MS10 specimen the one that exhibits the darker grey colour. Furthermore, the waste pre-treatment also influences the attained colour and aspect of the specimens, see samples MS10 and MS10r. When the waste is pre-treated (ground and sieved at $212 \mu \mathrm{m}$ ) a more homogeneous hue colour is obtained; contrarily, when no pre-treatment is applied, a rustic (non-uniform) aspect is achieved, given by the presence of larger particles.

Figure 1 also presents the colour coordinates of each sample, as well as the colour difference values $(\Delta \mathrm{E})$ between MS0 and MS10 samples fired in laboratory and industrial conditions. The increase of the MS amount promotes a noticeable brightness decrease $\left(\mathrm{L}^{*}-\right.$ 72.2 for MS0 and 49.2 for MS10) due to the iron richness of the mixes. Further, a decrease in the $b^{*}$ coordinate is also observed (12.4 for MS0 and 2.8 for MS10), while small variations are noticed in the values of the $\mathrm{a}^{*}$ coordinate (slightly negative). In Figure 8 the relationship 
between the $\mathrm{b}^{*}$ and $\mathrm{L}^{*}$ coordinates is presented. It can be observed that there is a notorious relationship between both coordinates and added MS quantity: higher the amount of MS incorporated in the stoneware paste lower are the values of both $b^{*}$ and $L^{*}$ coordinates. Lastly, the colour difference $(\Delta \mathrm{E})$ between MS0 and MS10 specimens sintered in the two tested conditions (laboratory and industrial furnaces) were 6.03 and 2.9, respectively. Thus, the difference between the colours of the MS0 samples is noticeable by anyone; whereas, for the MS10 samples they are perceptive to inexperienced observers [28]. The darker effect imposed by MS helped to hide colour differences between both firing conditions.

Figure 9 presents SEM micrographs and EDS of the fired specimens without and with 10 wt.\% MS, pre-treated and as-received, MS10 and MS10r, respectively. All specimens exhibit a quite uniform microstructure with few pores.

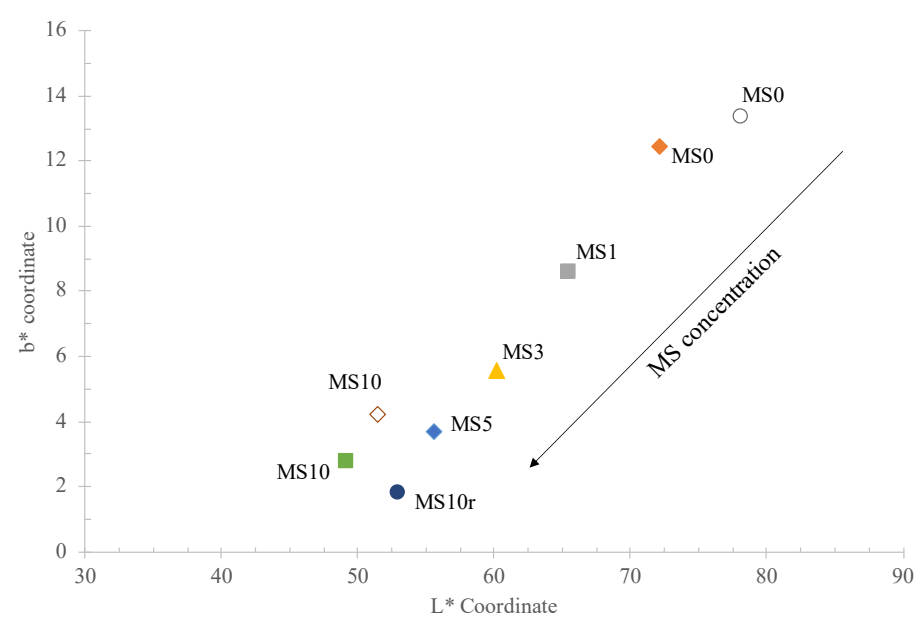

Figure 8. Graphical representation of changes on the colorimetric coordinates $b^{*}$ and $L^{*}$ of the fired samples in: laboratory furnace (filled symbols) and industrial furnace (open symbols).

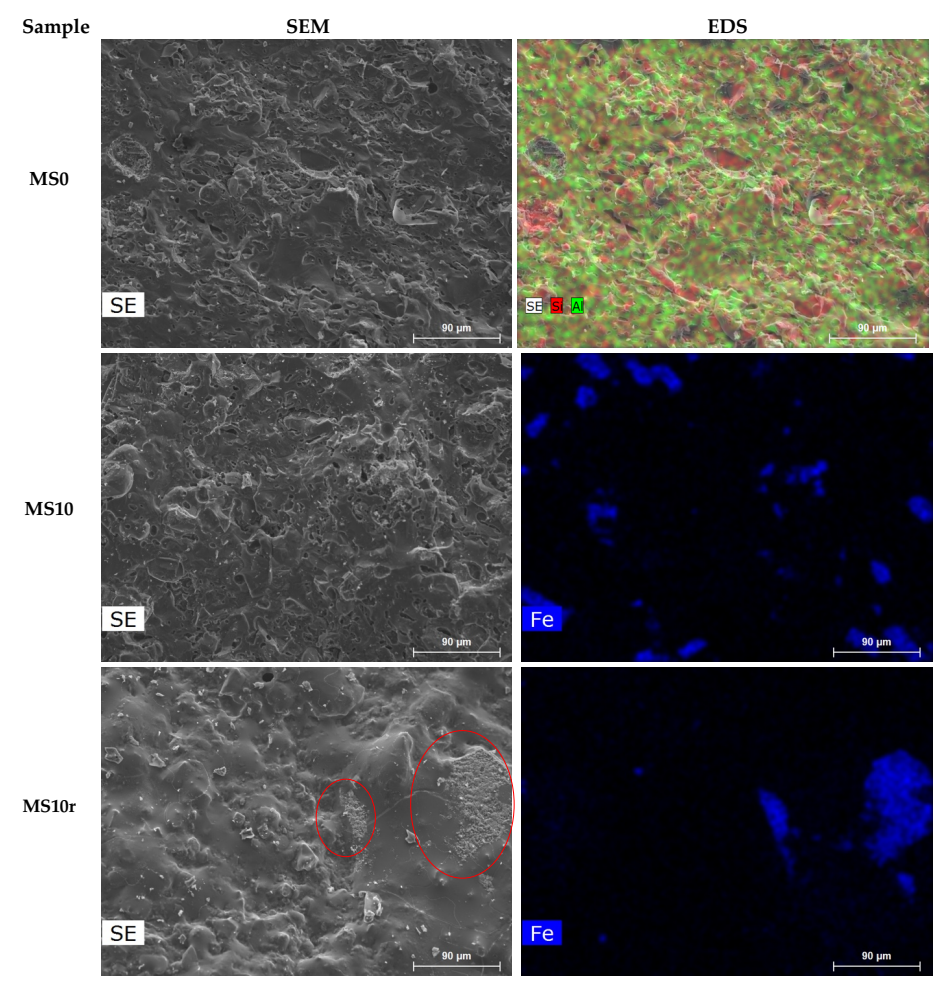

Figure 9. SEM micrographs and EDS of the fired specimens MS0, MS10 and MS10r. 
The EDS mapping images of the samples with $10 \mathrm{wt} . \%$ of MS shows that in MS10r sample the stain corresponding to the iron (blue) is stronger than that in MS10, in agreement with particle size differences.

\subsection{Evaluation of the Sintering Temperature Reduction}

The sintering process represents up to $65 \%$ of production costs in ceramic industries and contributes much to the environmental footprint of the products due to the high temperatures required. Therefore, the reduction of the firing temperature was also evaluated on specimens containing $10 \mathrm{wt}$ \% of MS. Temperatures tested were $1043^{\circ} \mathrm{C}, 1065^{\circ} \mathrm{C}$, $1092{ }^{\circ} \mathrm{C}, 1147^{\circ} \mathrm{C}, 1153{ }^{\circ} \mathrm{C}$ and $1160{ }^{\circ} \mathrm{C}$ (in the lab furnace); and $1165^{\circ} \mathrm{C}$ in industrial conditions. Colour changes are shown in Figure 10, while other technical parameters (water absorption, density and flexural strength) are given in Table 4 and Figure 11.

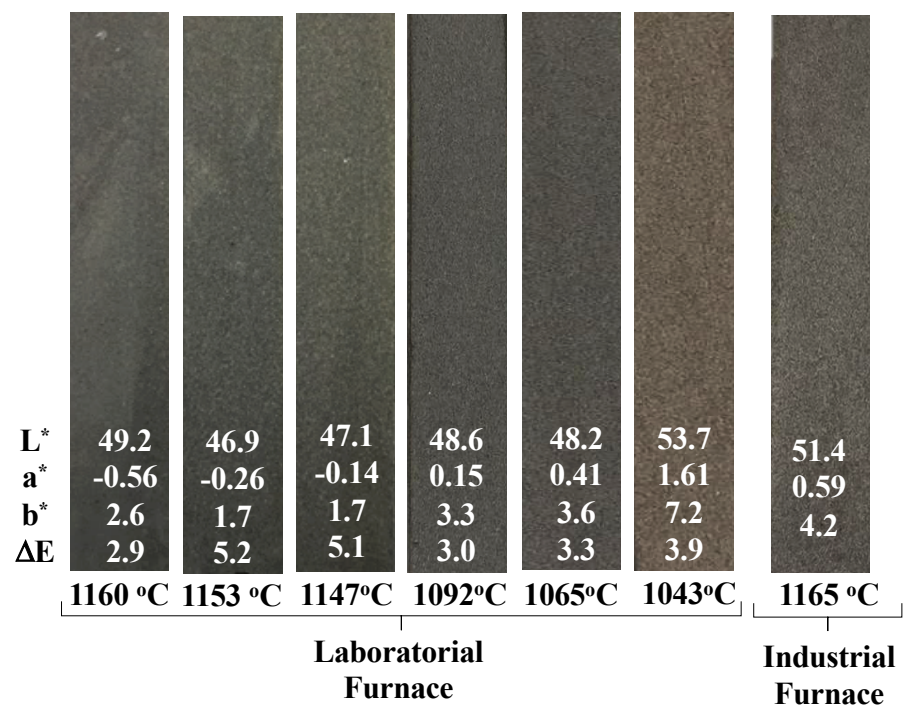

Figure 10. Specimens with $10 \mathrm{wt}$.\% of MS fired at different temperatures with the respective CIELab coordinates.

Colour changes are not expressive, particularly from $1065{ }^{\circ} \mathrm{C}$ onwards. Samples tend to darken when the temperature rises and acquire a strong greyish hue. Slight differences are perceived between lab and industrially fired samples.

Shrinkage upon firing varied between 8.8 and 9.7\% (higher with temperature enhancement) being the values within the admissible limits of the company. The water absorption tends to decrease with firing at high temperatures, being changes less pronounced (like colour) from $1065{ }^{\circ} \mathrm{C}$ onwards. Full density seemed to be achieved at $1147^{\circ} \mathrm{C}$ on samples fired in the lab furnace. This tendency is confirmed by the flexural strength variation (see Figure 11) with maximal value reached at that temperature. All samples show mechanical resistance above the minimum level (30 MPa). Differences between lab and industrially fired samples are explained by the prolonged exposure of the first at high temperature, since the cooling step is slower than in the industrial kiln.

In water absorption, three levels can be observed. In the first level, from 1165 to $1147{ }^{\circ} \mathrm{C}$, the water absorption remains very low (0.04 and $\left.0.09 \%\right)$; in the second level $\left(1092\right.$ and $1065^{\circ} \mathrm{C}$ ) the water absorption slightly increases ( 0.33 and $0.45 \%$, respectively) but the density of the specimens remains high; in the last level, at $1043{ }^{\circ} \mathrm{C}$, the density decreases to $2.24 \mathrm{~g} / \mathrm{cm}^{3}$ and the water absorption increases to $2.2 \%$. In this last case, the used firing temperature is not sufficient to create the necessary amount of liquid phase and therefore, the specimen presents a higher porosity. Hence, these results showed that it is possible to reduce the sintering temperature up to $1065^{\circ} \mathrm{C}$ once, at this temperature, the specimen's properties were not significantly affected and remain within the industrial limits. Consequently, the incorporation of $10 \mathrm{wt}$ \% of mill scale enables a reduction of 
$\approx 100{ }^{\circ} \mathrm{C}$ on the maximum temperature reducing the environmental footprint associated with the sintering process.

Table 4. Influence of the sintering temperature on the water absorption (WA) and geometric density (D) of the specimens.

\begin{tabular}{cccccccc}
\hline Furnace & \multicolumn{3}{c}{ Laboratory } & & & Industrial \\
\hline $\begin{array}{c}\text { Sintering } \\
\text { temperature }\left({ }^{\circ} \mathrm{C}\right)\end{array}$ & 1043 & 1065 & 1092 & 1147 & 1153 & 1160 & 1165 \\
\hline $\mathrm{WA}(\%)$ & $2.2 \pm 0.2$ & $0.45 \pm 0.05$ & $0.33 \pm 0.03$ & $0.09 \pm 0.02$ & $0.04 \pm 0.02$ & $0.07 \pm 0.05$ & $0.04 \pm 0.02$ \\
$\mathrm{D}\left(\mathrm{g} / \mathrm{cm}^{3}\right)$ & $2.24 \pm 0.01$ & $2.32 \pm 0.01$ & $2.32 \pm 0.01$ & $2.40 \pm 0.01$ & $2.25 \pm 0.01$ & $2.39 \pm 0.01$ & $2.27 \pm 0.01$ \\
\hline
\end{tabular}

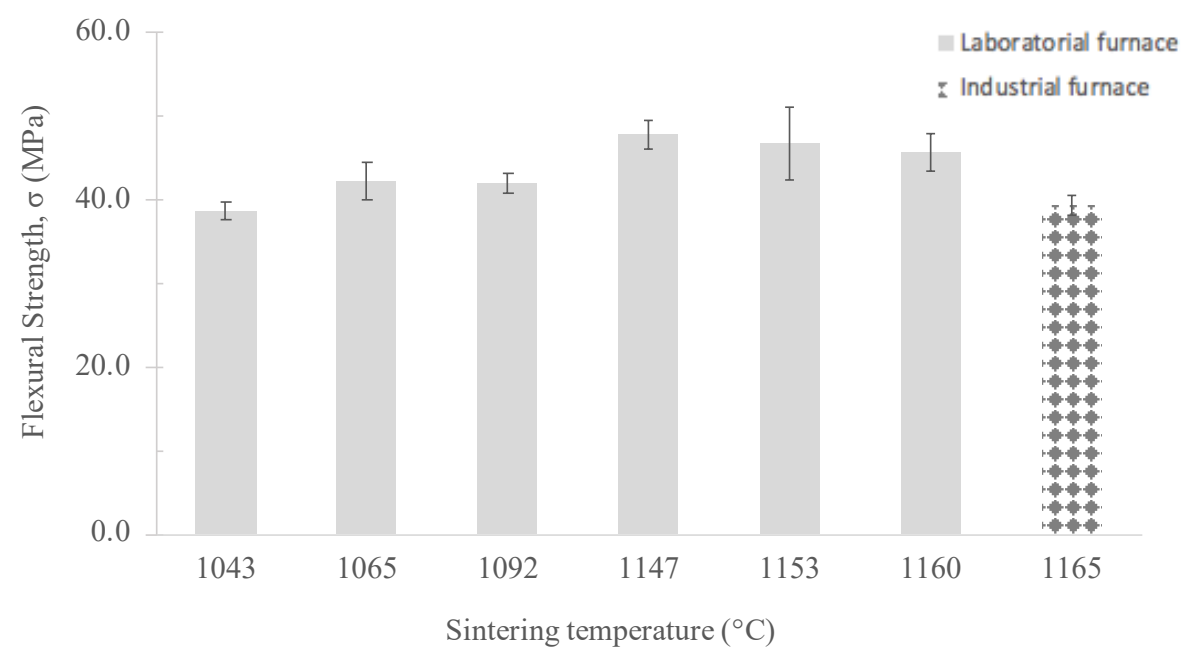

Figure 11. Influence of the sintering temperature on the flexural strength of the specimens containing $10 \mathrm{wt} . \%$ of MS.

\subsection{Leaching Behaviour}

Iron $(\mathrm{Fe})$, cadmium $(\mathrm{Cd})$ and lead $(\mathrm{Pb})$ amounts leached out from industrially glazed cups prepared with stoneware pastes containing distinct MS concentrations are presented in Table 5. The leached concentration of Fe is, for all the samples, lower than $50 \mu \mathrm{g} / \mathrm{L}$ being well below the maximum allowed concentration for drinking water, $200 \mu \mathrm{g} / \mathrm{L}$ [30]. Leached concentrations of $\mathrm{Cd}$ and $\mathrm{Pb}(<0.5$ and $<7.5 \mu \mathrm{g} / \mathrm{L}$, respectively) are also significantly below the maximum allowed value for cups, as defined by the EU Ceramic Directive 84/500/EEC $(20 \mu \mathrm{g} / \mathrm{L}$ and $200 \mu \mathrm{g} / \mathrm{L}$, respectively) [29]. These results assure the safe use of such products.

Table 5. Leached concentrations of tested elements from industrially produced cups with distinct MS contents.

\begin{tabular}{cccc}
\hline & \multicolumn{3}{c}{ Concentration $(\mu \mathrm{g} / \mathrm{L})$} \\
\cline { 2 - 4 } Samples & $\mathbf{F e}$ & $\mathbf{C d}$ & $\mathbf{P b}$ \\
\cline { 2 - 4 } & $\leq \mathbf{2 0 0}^{\text {(a) }}$ & $\leq \mathbf{2 0}^{(\mathbf{b})}$ & $\leq \mathbf{2 0 0}^{(\mathbf{b})}$ \\
\hline MS0 & $<50$ & $<0.5$ & 2.7 \\
MS1 & $<50$ & $<0.5$ & 7.4 \\
MS3 & $<50$ & $<0.5$ & 2.5 \\
MS5 & $<50$ & $<0.5$ & 4.7 \\
MS10 & $<50$ & $<0.5$ & 3.7 \\
\hline
\end{tabular}

(a) Max. value-drinking water: Council Directive 98/83/EC [30], (b) Max. values-mugs: EU Ceramic Directive $84 / 500 /$ EEC. 


\section{Conclusions}

The proof of concept of using MS as colouring agent of a stoneware paste was tested at laboratory and pilot plant scales allowing us to conclude that:

- Waste incorporation levels up to $10 \mathrm{wt} . \%$ are viable and the pastes produced with this amount assures the best combination of technical requirements, namely maximal flexural strength (45.6 MPa) and almost null water absorption $(0.07 \%)$.

- A dark grey hue can be achieved and this waste can be used to mask potential inhomogeneities on the pieces, substituting expensive commercial pigments.

- Energy savings can be attained with relevant economic and environmental benefits since the fluxing action of the waste anticipates maturation reactions upon firing, being possible to reduce the firing temperature by about $100{ }^{\circ} \mathrm{C}$.

- The developed materials are safe to use since the leached amounts of potentially hazardous species $(\mathrm{Fe}, \mathrm{Pb}$ and $\mathrm{Cd})$, tested according to the EU Ceramic Directive $84 / 500 /$ EEC on industrially produced cups, are well below the admissible limits.

Therefore, this work provides a high value-added application for steel wire drawing mill scale wastes, aligned with the new circular economy paradigm and able to contribute to a win-win industrial symbiosis: use of waste produced by the steel wire producer and reduction of carbon footprint (energy and primary resources saving) in ceramic industries.

Author Contributions: Conceptualization, I.S.V. and M.P.S.; data curation, I.S.V. and A.L.L.; funding acquisition, M.P.S.; investigation, I.S.V. and A.L.L.; methodology, I.S.V., A.L.L. and J.C.; project administration, M.P.S.; supervision, C.P., J.A.L. and M.P.S.; validation, I.S.V. and A.L.L.; writingoriginal draft, I.S.V.; writing-review and editing, J.C., C.P., J.A.L. and M.P.S. All authors have read and agreed to the published version of the manuscript.

Funding: This research was funded by Portugal 2020 through the European Regional Development Fund (ERDF) in the frame of the Operational Competitiveness Internationalization Programme (POCI) in the scope of the project ECOGRES + NG-POCI-01-0247-FEDER-033853 and in the scope of the project CICECO-Aveiro Institute of Materials, UIDB/50011/2020 and UIDP/50011/2020, financed by national funds through the Portuguese Foundation for Science and Technology/MCTES.

Institutional Review Board Statement: Not applicable.

Informed Consent Statement: Not applicable.

Acknowledgments: The authors gratefully acknowledge Fapricela-Indústria de Trefilagem S.A. for providing the mill scale.

Conflicts of Interest: The authors declare no conflict of interest.

\section{References}

1. OECD. Environment at a Glance: Climate Change. 2019. Available online: http://www.oecd.org/environment-at-a-glance (accessed on 22 April 2020).

2. Suleman, Y. Solid Waste Disposal and Community Health Implications in Ghana: Evidence from Sawaba, Asokore Mampong Municipal Assembly. J. Civ. Environ. Eng. 2016, 5. [CrossRef]

3. Eurostat. 2018. Available online: https://ec.europa.eu/eurostat/statistics-explained/index.php/Waste_statistics\#Total_waste_ generation (accessed on 22 May 2020).

4. UN, United Nations 2020. Available online: https://unric.org/pt/objetivo-12-producao-e-consumo-sustentaveis / (accessed on 22 May 2020).

5. Graedel, T.; Allwood, J.; Birat, J.P.; Buchert, M.; Hageluken, C.; Reck, B.K.; Sibley, S.F.; Sonnemann, G. Recycling Rates of Metals-A Status Report; UNEP: Paris, France, 2011.

6. FBI, Fortune Business Insights 2019. Available online: https:/ /www.fortunebusinessinsights.com/steel-wire-market-102581 (accessed on 15 October 2020).

7. Gade, N.; Verma, G.; Sen, R.; Pandel, U. Effect of Calcium Carbonate on the Reduction Behaviour of Mill Scale. Procedia Earth Planet. Sci. 2015, 11, 319-324. [CrossRef]

8. OECD. Steel Market Developments: Q2 2020. 2020. Available online: https://www.oecd.org/officialdocuments/ publicdisplaydocumentpdf/?cote=DSTI/SC(2020)1/FINAL\&docLanguage=En (accessed on 20 September 2020).

9. Bagatini, M.C.; Fernandes, T.; Silva, R.; Galvão, D.F.; Flores, I.V. Mill scale and flue dust briquettes as alternative burden to low height blast furnaces. J. Clean. Prod. 2020, 276. [CrossRef] 
10. Branca, T.A.; Colla, V.; Algermissen, D.; Granbom, H.; Martini, U.; Morillon, A.; Pietruck, R.; Rosendahl, S. Reuse and recycling of by-products in the steel sector: Recent achievements paving the way to circular economy and industrial symbiosis in europe. Metals 2020, 10, 345. [CrossRef]

11. Quddus, M.; Rahman, M.; Khanam, J.; Biswas, B.; Sharmin, N.; Ahmed, S.; Neger, A. Synthesis and Characterization of Pigment Grade Red Iron Oxide from Mill Scale. Int. Res. J. Pure Appl. Chem. 2018, 16, 1-9. [CrossRef]

12. Ueda, S.; Yanagiya, K.; Watanabe, K.; Murakami, T.; Inoue, R.; Ariyama, T. Reaction model and reduction behavior of carbon iron ore composite in blast furnace. ISIJ Int. 2009, 49, 827-836. [CrossRef]

13. Galvão, J.L.B.; Andrade, H.D.; Brigolini, G.J.; Peixoto, R.A.F.; Mendes, J.C. Reuse of iron ore tailings from tailings dams as pigment for sustainable paints. J. Clean. Prod. 2018, 200, 412-422. [CrossRef]

14. Low, K.O. Iron Oxide Pigments from Mill Scale. U.S. Patent 7,347,893, 25 March 2008.

15. De Gisi, S.; Romaniello, L.; Dalessandro, M.; Todaro, F.; Notarnicola, M. Recovery of iron rich residues from integrated steel making process by hydrated lime/molasses pressurised cold agglomeration. J. Clean. Prod. 2019, 233, 830-840. [CrossRef]

16. Shishegaran, A.; Daneshpajoh, F.; Taghavizade, H.; Mirvalad, S. Developing conductive concrete containing wire rope and steel powder wastes for route deicing. Constr. Build. Mater. 2020, 232, 117184. [CrossRef]

17. Velumani, P.; Manikandan, P. Steel mill scale waste and granite powder waste in concrete production-An experimental study. Mater. Today Proc. 2020. [CrossRef]

18. Ozturk, M.; Depci, T.; Bahceci, E.; Karaaslan, M.; Akgol, O.; Sevim, U.K. Production of new electromagnetic wave shielder mortar using waste mill scales. Constr. Build. Mater. 2020, 242, 118028. [CrossRef]

19. Khaerudini, D.S.; Prakoso, G.B.; Insiyanda, D.R.; Widodo, H.; Destyorini, F.; Indayaningsih, N. Effect of graphite addition into mill scale waste as a potential bipolar plates material of proton exchange membrane fuel cells. J. Phys. Conf. Ser. 2018. [CrossRef]

20. Bugdayci, M.; Deniz, G.; Ziyreker, C.; Turan, A.; Oncel, L. Thermodynamic modeling and production of FeCo alloy from mill scale through metallothermic reduction. Eng. Sci. Technol. Int. J. 2020, 23, 1259-1265. [CrossRef]

21. Ovčačíková, H.; Vlček, J.; Matějka, V.; Juřica, J.; Maierová, P.; Mlčoch, P. The effect of temperature and milling process on steel scale utilized as a pigment for ceramic glaze. Materials 2020, 13, 1814. [CrossRef] [PubMed]

22. Legodi, M.A.; de Waal, D. The preparation of magnetite, goethite, hematite and maghemite of pigment quality from mill scale iron waste. Dye. Pigment. 2007, 74, 161-168. [CrossRef]

23. Bezzina, B.; Abedghars, M.; Bendjama, H.; Bouhouche, S. Valuation of mill scale as iron pigments for painting anticorrosive. Nat. Technol. 2017, 17, 1-6.

24. Ferraz, E.J.M.d.O. Caulinos de Alvarães: Propriedades e Aplicações Cerâmicas. Ph.D. Thesis, Universidade de Aveiro, Aveiro, Portugal, 2004.

25. Vilarinho, I.; Carneiro, J.; Pinto, C.; Labrincha, J.; Seabra, M. Development of Coloured Stoneware Bodies through the Incorporation of Industrial Cr/Ni Electroplating Sludge. Sustainability 2021, 13, 1999. [CrossRef]

26. EN:1217, B: BSI Standards Publication Materials and Articles in Contact with Foodstuffs: Test Methods for Water Absorption of Ceramic Articles; BSI Standards Publication: London, UK, 1998; p. 10.

27. CIE. CIE. CIE Recommendations on Uniform Color Spaces, Color-Difference Equations, and Metric Color Terms. Color Res. Appl. 1977, 2, 5-6. [CrossRef]

28. Mokrzycki, W.S.; Tatol, M. Colour difference Delta-E. A survey. Mach. Graph. Vis. 2011, 20, 383-411.

29. Council of the European Union. Council Directive of 15 October 1984 on the Approximation of the Laws of the Member States Relating to Ceramic Articles Intended to Come into Contact with Foodstuffs; Council of the European Union: Brussels, Belgium, 1984.

30. European Parliament and Council. Council Directive 98/83/EC of 3 November 1998 on the Quality of Water Intended for Human Consumption; European Parliament and Council: Brussels, Belgium, 2010. [CrossRef]

31. Colpas-Ruiz, M.A.; Gnecco-Molina, C.; Jiménez-Rodríguez, G.A.; Pérez-Mendoza, J.A.; Higuera-Cobos, Ó.F. Synthesis of an Anticorrosive Pigment by Thermal Treatment of Iron Oxides from Steel Industry Wastes. Rev. Fac. Ing. 2019, 28, 43-58. [CrossRef] 